\title{
Religious research as kingpin in the fight against poverty and AIDS in the Western Cape, South Africa
}

\author{
Johannes C Erasmus, H Jurgens Hendriks* \\ en Gerbrand G Mans \\ Universiteit van Stellenbosch
}

\begin{abstract}
This article describes the researchers' efforts to apply the principles of Participatory Action Research (PAR), specifically participation, through the direct involvement of church members in the research. It includes involving them in the design of questionnaires, training and utilizing them as fieldworkers, and finally disseminating the results of the research via workshops aimed at strategizing for change. The research is based on two hypotheses, the first being that, churches and their members are intensely involved in serving both the needs of their own members, as well as the needs of the larger community; and secondly, that churches do not work alone, but are part of networks with other agencies to accomplish their goals. At the outset the article outlines the challenges and points of departure, followed by a chronological account of how this approach was applied in Paarl, a South African community. Finally, an overview of the results of the project is provided.
\end{abstract}

\section{SCOPE AND PROBLEM}

Theology is by its very nature contextual (Hall 1991:69). Hence, theological research in (Southern) Africa cannot blindly follow the methodology developed in first world countries. Ten years after the 1994 miracle of South Africa's peaceful transition to democracy our challenges are clear and a realistic appraisal of the importance of working together across all kinds of boundaries

\footnotetext{
* This material is based upon work supported by the National Research Foundation under Grant Number 2054070. Any opinion, findings and conclusions or recommendations expressed in this material are those of the author(s) and therefore the NRF does not accept any liability in regard thereto. Financial assistance is acknowledged from the following institutions: Anglican Church, Athlone Institute, BUVTON, DAWN Africa, Hannelie Rupert Getuienisfonds, Mergon Trust, Dutch Reformed Church in Western Cape and the Circuit of the Dutch Reformed Church in Paarl.
} 
should be clear. There are limited resources and daunting challenges in Africa. This also applies to the universities on the continent.

This article has three points of departure. The first is methodological. Van der Ven (1998:1-89) and Heitink (1999:15-170) describe the history and development of Practical Theology. Within theology as a discipline, this subdiscipline may be described as a hive of activity ever since the Enlightenment. By and large one can describe the developments within theology as being the result of the modernisation of society, the influence of the hermeneutical approach and the fundamental philosophical shifts that took place affecting epistemology. Theology is no longer practised exclusively in a deductive style with an authoritative ethos.

Van der Ven (1998:89-112) describes different ways in which Practical Theology can relate epistemologically to other sciences, namely in mono-, multi-, inter- and intradisciplinary ways. In a monodisciplinary approach Practical Theology is done in a deductive way, rather authoritatively and in a top-down style, applying theory in practice. There is very little dialogue with the contextual reality. In a multidisciplinary model several scientific disciplines work independently of one another to do research on a problem. Theology then uses the results of the "other social sciences" and becomes highly dependent on the work done by other disciplines. The interdisciplinary approach stresses interaction and co-operation between different social sciences in which the researchers work together as a team. Van der Ven (1998:99-101) is doubtful whether this is a viable approach in his European context, where the church and theology are experiencing a reality totally different from that of Africa. He therefore opts for an intradisciplinary approach in which theology has to master the different empirical research methodologies and instruments. We preferred not to take this road and opted for an interdisciplinary approach.

Because of its epistemological roots, Participatory Action Research (PAR) is a very useful methodology in doing research in development. ${ }^{1}$ The epistemological roots of PAR are found in critical theory, where the purpose of science is "uncovering the repressive conditions that leave people bound and alienated. [Brian Fay's] plea is for a social science that will transform the human condition and empower individuals to emancipate themselves" (in Babbie \& Mouton 2001:44). Similarly, the driving force behind PAR is "the ideology that a self-conscious people, those who are currently poor and oppressed, will progressively transform their environment by their own praxis.

\footnotetext{
${ }^{1}$ Babbie \& Mouton (2001:313 ff); Prozesky \& Mouton (2001:537-550); Schurink (1998:405418).
} 
In this process others may play a catalytic and supportive role, but will not dominate" (Rahman 1993:82).

Research in South Africa is normally conducted on the basis of small samples taken from the entire population. These results usually do not paint the full picture at a local community level and even less of communities on the fringes of society. The end result is that these data sets are not useful in mobilising local communities for action.

The assumptions of PAR have important consequences for developing a research methodology, the two most important of which are probably the participation of people from the community (Prosezky \& Mouton 2001:542) and the mobilizing/empowerment of the community (Prosezky \& Mouton 2001:546). In PAR the power moves from the researcher to co-ownership between researcher and subject of study. The role of the researcher changes to that of change agent or facilitator (Prosezky \& Mouton 2001:541).

Secondly, within development theory we take as point of departure the critical role of FBOs as agents of social development. Recently, the role of FBOs in development has been appraised (Swart \& Venter 2001:482-95). Local faith communities (congregations) or faith-based organisations (FBOs) provide a host of services to their local communities, the nation and sometimes the world. Congregations provide public space. They offer a wide array of social assistance and they are channels for a large amount of volunteer activity. How can the FBOs in local communities be empowered and mobilised to fulfil their full potential in the sphere of social development? Similarly, how can Unit for Religion and Development Research (URDR) initiate a research process in which researchers from the University and members of the community/FBOs will participate as equal partners? URDR was faced with the challenge of developing a research methodology that would enhance the role of FBOs as development agents in local communities.

Thirdly, within a development strategy participation by the local community is critical in people-managed development. When dealing with problems such as poverty it is essential to involve local communities (cf Cochrane et al. 1991; Fals-Borda and Rahman 1991; Prozesky and Mouton 2001; Rahman 1993; Schurink 1998). We needed a methodology that involves local communities. In implementing our approach, we struggled with several questions. What information is needed that will improve both the functioning of FBOs and the daily lives of people in the community?

Furthermore, in what ways could the local community participate in the project in ways that would preserve the integrity of their contribution? We realised that the sustainability of the project would depend on the participation of all role players in both the planning and execution of the project. 
Within these three points of departure the Church and Community Research Project was launched at the end of 2001 at the Unit for Religion and Development Research (URDR), a Unit in the Department of Practical Theology and Missiology. A pilot study was conducted in 2002 in Paarl', where all places of worship were mapped using Global Positioning System (GPS) technology; $10 \%$ of households were surveyed by means of a questionnaire; and a questionnaire was distributed to some members of the leadership of congregations. In conducting this research, people from the community itself were trained in research methodology in order to gather the data. The following aims were set for the research project:

- To investigate what Christian churches of all denominations in the Paarl community are doing to provide services to their communities with regard to the most severe problems of HIVIAIDS \& TB, unemployment, sexual violence and crime, and substance abuse;

- In addition, what are the organizational connections through which and together with whom they achieve their aspirations? ${ }^{3}$

The researchers worked with the following hypothesis:

- Churches and their members are intensely involved in serving both the needs of their own members as well as the needs of the larger community;

- Furthermore, churches do not work alone, but are part of different networks with other agencies (including churches, governmental and non-governmental organizations) to accomplish their goals. They collaborate with different kinds of organizations which enable them to render these services.

The article describes the researchers' efforts to apply the principles of PAR, specifically participation, through the direct involvement of church members in the research: involving them in the design of the questionnaires, training and utilizing them as fieldworkers, and finally disseminating the results of the

\footnotetext{
${ }^{2}$ Paarl is a prominent town in the Western Cape with 110,000 inhabitants.

${ }^{3}$ Based on these aims, the following research question was formulated: What are churches of all denominations in Paarl doing to provide services to address unemployment, HIV/Aids, sexual violence, crimes against women and children, and substance abuse, and what networks exist through which they pursue their goals?
} 
research via workshops to strategise for change. This is followed by an overview of the results and conclusions based on the methodology and hypotheses.

\section{THE RESEARCH PROCESS}

The process describes the efforts of the researchers to create space for the community to participate in the research.

\subsection{The launch}

The research process followed in Paarl will now be discussed. The knowledge and skills of the interdisciplinary team were invaluable in this process, but more than anything else it was the input from the community itself that challenged the process and the researchers, who had to improvise and to adapt.

The Paarl launch was held on $26^{\text {th }}$ March 2002 and various people from business, local government and denominations were invited. After visits to individual leaders, fraternals, NGOs and local government departments, the first "official" meeting was held at the Faculty of Theology in Stellenbosch. The project was discussed and inputs from different people helped to streamline the initial process. It was decided that both primary and secondary data were to be used in the research. The primary data originated from a questionnaire survey, from all places of worship which were to be located and marked geographically by using GPS technology, and from structured interviews with church leadership. The secondary data, pertaining to the prevalence of crime and the incidence of HIVIAids, were obtained from the South African Police Service (SAPS) and the various health-related services in Paarl.

\subsection{Questionnaire design}

On $24^{\text {th }}$ April 2002 an invitation was extended to all people in Paarl via the local newspapers to participate in a workshop for the design of the questionnaire. The workshop was attended by 20 representatives and held over two days, $13^{\text {th }}$ to $14^{\text {th }}$ May. During this workshop representatives from Paarl were led through various exercises by the Department of Sociology, in order to prioritise the most severe social and welfare issues in Paarl. The representatives constructed the first round of questions for the questionnaire. We took these problems and questions that were identified and from them compiled a comprehensive questionnaire.

A second workshop was held on $25^{\text {th }}$ June, to which the representatives were again invited. The questionnaire was scrutinised to see 
whether it reflected the process and content of the previous workshop. Some additional suggestions were made about the questionnaire. The researchers at the Unit developed a final version of the questionnaire. The questionnaire was self-administered and available in both Afrikaans/English and English/isiXhosa in order to make it accessible to everybody.

The purpose of the questionnaire was to establish the number of people involved in services rendered by the church and other organisations, the number of people who receive assistance and the community's perceptions concerning the church's involvement in social services.

\subsection{GPS mapping}

For a while the questionnaire survey and everything surrounding it moved to the background and we proceeded with the task of obtaining the other primary data, namely the location of the places of worship in Paarl. These places of worship did not include places where prayer meetings took place during the week, but only venues for churches' official meetings on Sundays, whether in a separate building, house, classroom in a school, et cetera.

The local co-ordinator organised 15 volunteers from local churches to be at a training session on the $29^{\text {th }}$ July 2002 at a church in Paarl. These people were trained in the use of GPS handheld units. In this session Paarl was divided into 18 blocks with the help of the local residents, using a map of the town. We had the advantage of having GIS technology available to us and a map of each of the identified blocks was produced on the spot. Each team then received such a map, which helped them to co-ordinate their investigations and prevented teams from duplicating work, thus saving time.

Each team was dropped off in their designated area and they literally walked up one street and down the next to locate places of worship. Besides marking the places of worship, the fieldworkers also had to establish the name of the church, the size of the congregation and how regularly it met. The fieldwork was done from $30^{\text {th }}$ July to $2^{\text {nd }}$ August 2002. The data were downloaded onto a computer and ESRI's ArcView shapefiles created from the data.

\subsection{Questionnaire survey}

After the phase of locating the places of worship, it was time to carry out the survey of the questionnaire designed earlier. Conducting the survey was an enormous logistical challenge. Firstly, the question of the distribution of questionnaires had to be considered. After considering several options, we decided to work with churches. This was, firstly, because of the point of departure, namely the emphasis on participation, but also because of the 
potential of churches in the development of the community and, lastly, it was important from a strategic point of view - if the churches were involved in the collecting of data, they might also be involved in promoting development outcomes following the results of the research. Furthermore, most churches have established infrastructures and access to households in their area.

The question of sample size was also considered. In order to get a representative sample it was decided to draw a $10 \%$ spatially stratified sample from the total number of households in Paarl. To spatially stratify the Paarl households, thirty geographical areas were established. These 30 areas were created by grouping together enumeration areas, with the same demographic profile, using factor analysis. The factor analysis was conducted on socioeconomic variables from the Census of $1996 .{ }^{4}$ Each one of these 30 areas was then further divided into smaller sub-areas, each having not fewer than 100 and not more than 200 households. A proportional number of questionnaires were distributed in each one of these sub-areas, with 10 to 20 questionnaires ultimately having to be distributed in each.

We wanted to use churches as instruments of research and we had 30 areas established through factor analysis. How were we going to link the 30 areas with their sub-areas with the church as instrument? How were we continuously going to facilitate the church's involvement in the project? The following strategy was designed. In each of the 30 sample areas a congregation that worshipped in the area was selected to take responsibility for the sample area. The choice of congregation depended on two factors: it had to be well represented in the area and there needed to be an even representation of denominations. We approached the leaders of the churches either by telephone or by making an appointment. On $15^{\text {th }}$ August we held a presentation for the 30 leaders. A folder was given to each one, including a map of their area of responsibility; the folder also contained a document explaining the research process, another explaining what is expected of them and a third explaining the work of the fieldworkers.

The most important job of the leadership was to mobilise responsible fieldworkers from their churches, give each fieldworker's folder to him/her and receive it back once the fieldwork was completed. The leaders received the folders on Friday $30^{\text {th }}$ August. Approximately 150 fieldworkers were trained on two occasions, i.e. $31^{\text {st }}$ August in Paarl East and $3^{\text {rd }}$ September at the Catholic Church in Mbekweni. Each fieldworker received a map of the sub-area and a map at smaller scale of Paarl for orientation. On the map of the sub-area, house numbers and street names were indicated. The location where the

\footnotetext{
${ }^{4}$ Factor analysis summarises the important relationships between the variables in the form of a few basic patterns called factors (Davies 1984; Murdie 1969).
} 
questionnaires were dropped was marked on this map in order to assist the fieldworker when he/she had to collect the questionnaires. Again the use of outputs from the GIS were crucial in assisting the fieldworkers in gathering the data. In the township of Mbekweni, where literacy was a problem, fieldworkers helped respondents to complete the questionnaire.

Through the local newspaper, the Paarl Post, and the local radio station, Radio KCC, the community was informed that fieldworkers might knock on their door with a questionnaire. Churches received an announcement to read on Sunday and leaders were asked to pray for the project on the two Sundays of the fieldwork.

Approximately 2500 questionnaires were distributed in the 30 sample areas. Only one area's leadership did not co-operate. Approximately 1800 questionnaires were returned (72.9\%). Two congregations managed a $100 \%$ return rate.

\subsection{Interviews with leadership}

The purpose of the interviews was to complement information gathered from the community with information from the leadership. Secondly, the purpose was to explore the partnerships within which churches operate. With this information we would be able to describe churches' partnerships with other churches and NGOs in order to see the bigger picture of the faith-based social service network.

Initially we thought that an interview with all churches marked with the GPS would be conducted. This proved to be almost impossible. Instead it was decided to design a simple questionnaire and deliver it to a sample of 30 leaders representing both the demographics and the denominational spread of Paarl. The questionnaire consisted of questions regarding leadership (fulltime/part-time, theological training, etc.), churches (members, age, etc), ministries and partnerships. Leaders were asked to distinguish between five aspects of involvement, namely immediate relief, projects/ministries, preventative action, counselling and lobbying. We received 26 questionnaires back.

\subsection{Secondary data}

During the questionnaire design workshops the representatives identified specific problems which were prominent in the community of Paarl and which they wanted to address. For some of these problems other sources of data were already available, for example information pertaining to HIVIAids, unemploy-ment, and sexual and/or violent crimes. 
HIVIAids data were available from the various health-related services such as the local clinics and hospitals. The research group contacted the various institutions, asked permission and received the relevant data. Data related to unemployment were even more straightforward because we had access to data from Stats SA's 1996 population census. Data pertaining to sexual and/or violent crimes were provided by the South African Police Service (SAPS). We approached the Crime Information Analysis Centre (CIAC) departments of the various stations, applied for permission to research the data and received the crime data we needed.

\subsection{Dissemination of information}

We wanted to report the results of the information gathered by the community in such a way that they were accessible to everyone. This is a key element of PAR methodology. Accessibility in our context means that people in the community should be able to understand and use the data. This will, we hope, lead to a better understanding of the problems which the local people identified; empower them to do something about these problems; and bring them into contact, through networking, with the available resources.

Thus, a series of community workshops based on the issues identified by the community were held in the various communities. The purpose of the workshops was:

- To communicate the research results to members of the community/FBOs and their leaders.

- Members of the community/FBOs were given the opportunity to refine and complement the research results in terms of their own life experiences and knowledge.

- Action objectives and plans for social development were collectively formulated by university researchers and community/FBO members. On the basis of this collective reflection a sustainable, long-term university-community partnership was established through which resources on both sides were mobilised, links and networks were forged, and the action plans implemented.

On the other hand, technology (GIS) ${ }^{5}$ played a key role in the workshops. GIS allowed the researchers to maintain the link between data and the

\footnotetext{
${ }^{5}$ A Geographical Information System (GIS) is a computer system for capturing, storing, analyzing, manipulating and displaying spatial (geographical) and non-spatial (attribute) data.
} 
geographical origin of the data. The result was the production of meaningful, attention-grabbing maps that visually illustrate important issues. The software also enables people to gain new insights into issues and enhances communication between them (Jones 1997; Queralt \& Witte 1998:455-67). All the datasets from the research, secondary and primary, were incorporated into a GIS. The overlap between different issues in specific geographical areas could therefore easily be identified. When necessary, the maps were given on an aerial photograph background through which everything looked much more "familiar" and people could recognize what was well known to them.

For the purpose of the dissemination of the results the URDR formed a partnership with Valcare, a faith-based NGO in Paarl. Together we organised one general feedback session, followed by specific workshops, one on each of the research topics: unemployment, HIV/Aids, sexual violence against women and children, and substance abuse.

\section{RESULTS - AN OVERVIEW}

It is impossible, due to spatial limitations, to discuss the detail of the results. Hence an overview of the results is provided.

\subsection{GPS - all places of worship (See Figure 1)}

120 places of worship were marked by the fieldworkers. The dots (see Figure 1) on the map show all the places where people worship. It is clear from the map that churches have a presence in almost every area in Paarl; where people live, there are churches. However, in areas $G$ and $M$ there are no churches. People who live in area $G$ walk to a school nearby in area $H$, where 9 different churches worship in different classrooms of a primary school on a Sunday.

\section{2 $10 \%$ sample survey with questionnaire (Tables 1-6)}

The purpose of the survey was to establish how many people were involved in services rendered (by churches and organizations), how many people received assistance and what the community's perceptions were concerning the role of the church. The involvement, assistance and perception questions centre on the four topics of the research: unemployment, HIVIAids ${ }^{6}$, sexual and/or violent crimes against women and children ${ }^{7}$ and substance abuse. However in the discussion below only three will be touched on: unemploy-

\footnotetext{
${ }^{6}$ The results of the project pertaining to HIVIAids were discussed in Hendriks \& Erasmus \& Mans (2004).

${ }^{7}$ The results of the project pertaining to sexual violence were discussed in Erasmus \& Mans (2005).
} 
ment, HIVIAids and sexual and/or violent crimes against women and children. Several statements regarding the church were also tested. The results of the questions relevant to the topic are given.

In the questionnaire there were three different options for a person to indicate how they were involved or received assistance. Similar categories were used for involvement and assistance received. Firstly a person could be involved in providing direct assistance to a person, for example home based care for people with HIVIAids (or they could be assisted in this way).

Secondly, respondents could be involved (or assisted) in preventative actions, for example informing women about their rights and what to do if they are involved in an abusive relationship. Lastly, a person could provide (or receive) counselling to persons in need.

Tables 1 to 6 show the results in percentages. The following abbreviations were used in the tables:

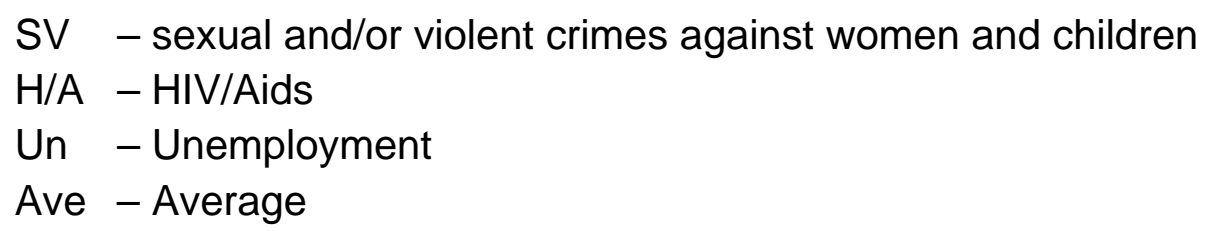

The results regarding involvement are shown in Table 1. Slightly more people are directly involved than are involved in preventative or counselling actions. The issue that attract most volunteers is HIV/Aids, followed by sexual violence and unemployment. Of all the variants most people in the community volunteer for preventative action regarding HIV/Aids.

The results for people who received assistance are shown in Table 2. The same categories were recorded, namely direct assistance, preventative activities and counselling. The average percentages are slightly lower. Consistent with Table 1, most people recorded receiving assistance for HIV/Aids followed by sexual violence and unemployment.

Tables 3-5 show the perceptions regarding the church's involvement (direct action, preventative action and counselling) with victims of sexual violence, HIVIAids and unemployed people. In Table 3 it is apparent that there is very little resistance against the church being directly involved. People were mostly positive (when "Yes" and "Certainly" are combined) about the church being involved with victims of sexual and violent crimes, followed by HIV/Aids and unemployment. Interestingly, the biggest percentage in the category "unsure" was for unemployment.

Table 4 contains the perceptions regarding the preventative action of the church. Although the average positive percentage is positive (when "Yes" and "Certainly" are combined), the issue people were least positive about is 
unemployment (56.1\%). It is clear that the community is not altogether sure whether it is the role of the church to be involved in preventative action with unemployed people. Respondents felt most positive about the church involvement with HIVIAids (72.4\%).

Table 5 shows that people are positive (when "Yes" and "Certainly" are combined) about the church counselling victims of sexual violence (73.2\%), followed by HIVIAids and unemployment.

In Table 6 the results of three statements regarding the church are summarized. The first question deals with the issue of better co-operation between churches, the second with the statement that the church does not care for the poor, and the last with the question of whether the church should co-operate with government and NGOs to address problems in the community.

There is strong agreement amongst respondents that there should be better co-operation between churches (the sum of agree and agree strongly is 91.5\%). More variation emerges from the second statement that the church does not care for the poor. An average of 55.2\% disagree with this statement. The last statement regarding co-operation between church and government or church and NGOs also provides interesting results. An average of $80.7 \%$ feel positive (when agree and agree strongly is combined) about such cooperation.

Summarizing Tables 1-6 the following points stand out:

- Most people volunteer their services in the HIVIAids field, followed by sexual violence and unemployment (Table 1).

- Most people are involved in direct action, followed by counselling and preventative action (Table 1).

- Most people reported receiving assistance in the HIVIAids field, followed by sexual violence and unemployment (Table 2).

- Most people reported receiving preventative assistance followed by counselling and direct action (Table 2).

- The aspect of service that people feel most positive about seems to be counselling, followed by direct action and preventative action (Table 35). 
- The area which people feel most positive that the church should be involved in seems to be victims of sexual and violent crimes, followed by HIVIAids and unemployment (Table 3-5).

- People in the community feel very strongly about better co-operation between churches (Table 6).

- $55.1 \%$ of the community disagree with the statement that the church does not care for the poor. However, a substantial $22.8 \%$ agree (Table $6)$.

- Lastly, the community feels strongly about co-operation between church and government, and between church and NGOs.

\subsection{Leadership questionnaire}

17 churches recorded involvement with the unemployed. Eleven of the seventeen were involved in immediate relief. All of these had to do with food, for example, soup kitchens, food parcels, et cetera. Three of the seventeen congregations recorded projects/ministries. Two of these had to do with food parcels and one involved food at a crèche. One church recorded involvement in a life skills project with high school children in a poor community. A further two of the seventeen recorded that they were involved in counselling unemployed members of their congregations. A total of 81 volunteers were involved in the seventeen congregations' activities.

Eight congregations recorded partnerships with either NGOs or denominational offices. Six of the eight had to do with immediate relief work. The other two were a sewing group and adult education classes. A total of 54 volunteers were involved in these activities.

Only two churches were involved in rendering services to victims of sexual and/or violent crimes. In both instances services were provided in partnerships with other organisations. The first is a Dutch Reformed church involved in a peace garden project in Paarl East and the other is the Catholic Church in partnership with the Catholic Welfare Department providing counselling to victims in Mbekweni. 23 volunteers are involved.

Regarding HIVIAids, seven congregations render some form of service either alone, or in partnership with another organization or, sometimes, both. These services include blankets and clothes, visitation, counselling, food parcels, information distribution and families fostering Aids orphans. Approximately 98 people volunteer for these services. 
Two churches with seven volunteers were involved in services to victims of substance abuse. Both these churches have their own ministries and partner with a faith-based NGO to render services.

\section{CONCLUSIONS}

The Church and Community Research Project represents the Unit's search for a methodology that would address the three points of departure of this article. The paradigm of PAR provides a useful framework to develop a methodology when doing grassroots theological research. The research team made a concerted effort to involve the local community, specifically members of churches, in a meaningful way. One cannot adequately describe contextualized PAR methodology development in the abstract. Every step was negotiated with the representatives of the communities.

With regard to the first hypothesis, we are positive that churches have the potential to influence the process of reduction of poverty in South Africa. In South Africa the church is the strongest and most influential non-governmental organisation (NGO), reaching on average 54\% of the Christian population weekly (World Values Survey 2000). Neither the government nor any other NGO can reach and influence the public more regularly and consistently than FBOs can. Moreover, more than three quarters of the population have indicated that they are affiliated with the Christian religion (79.8\% - Census 2001). Affiliation to the Christian religion increased from 45.7\% in 1911 to $79.8 \%$ in 2001 (see Hendriks 2003:6; Hendriks \& Erasmus 2001:41-65; 2005:88-121; and Erasmus \& Hendriks 2003:80-96). In Paarl the percentage affiliated with the Christian religion in 2001 was as high as 89\% (Erasmus \& Mans 2004:11).

Based on the results of both the sample survey and the leadership questionnaire, it is evident that a remarkable percentage of community members are involved in their personal capacity as well as through churches with the four issues researched in Paarl through direct action, preventative action and counselling. Almost as many people reported receiving assistance, which attests to the very high level of volunteer activity. In areas where people are more exposed to these problems, it seems as if volunteers are more involved than in areas where the problem is less prevalent (Erasmus \& Mans 2005:11).

If one reflects critically on the survey and data received from the leaders, it is also clear that only a small percentage of the volunteers channel their activity through churches or church structures. Thus, one can assume that these people are either involved with other NGOs serving in the 
community or more probably involved in their personal capacity with friends (in the neighbourhood) or family in need. Nevertheless, it seems that churches as organisations are not very deeply involved with the social needs of either their members or those of the larger community.

It is also clear that the community is positive about the church rendering services to victims, specifically in the fields of sexual violence and crime and through counselling. It is interesting that most churches report involvement through direct assistance regarding unemployment. From the community's point of view, it seems from the perceptions in the survey that this is the service least expected from churches.

Thus, the researchers found the first hypothesis to be partly true. Though members of churches are very much involved in serving the needs of people in the community, it is less true of churches as organisations. The reasons for the latter are found in the conclusions of the second hypothesis. Secondly, hypothesis 2 was also confirmed. There are approximately 43,000 Christian faith communities (Froise 1999:37) in South Africa and the infrastructure of these churches reaches into every corner of our country. The potential of the religious sector in South Africa, through its various FBOs, enables it to play a major role in fostering meaningful networks of care and development. There is a growing consensus that the endemic problems faced in South African society cannot be effectively dealt with without the cooperation or even leadership of FBOs. The dense and widespread location of Christian places of worship (see Figure 1) in Paarl is evidence of the networking potential of churches.

Following on the conclusion above that only a small percentage of volunteer activity is channelled through church structures, is it clear (from the data received from the leadership) that some churches recognise that the capacity to address the problems lies outside of the churches. As a consequence churches seek partnerships with these NGOs. Hence a pragmatic model of co-operation seems to develop where NGOs render services utilizing churches' volunteers, finances, infrastructure (including buildings) and communication.

There are also churches that successfully render services to the community. These services depend greatly on the pastoral leadership of that church.

Furthermore, results from the survey suggest that the community is very positive about better co-operation between churches as well as between churches and government/NGOs. In that sense churches do have a mandate from the community to seek ways of collaboration and partnership. 


\section{Works consulted}

Babbie, E \& Mouton, J 2001. Practice of social research. Oxford: University Press.

Cochrane, J R \& De Gruchy, J W \& Petersen, R 1991. In word and deed: Towards a practical theology for social transformation. Pietermaritzburg: Cluster Publications.

Davies, W K D 1984. Factorial ecology. Guildford: Gower.

Erasmus J C \& Hendriks, H J 2003. Religious affiliation in South Africa early in the new millennium: Markinor's World Value Survey. Journal of Theology for Southern Africa, 117, 80-96.

Erasmus, J C \& Mans, G 2005. Churches as service providers for victims of sexual violence and crime: A case study from the Paarl community. Acta Criminologica 18(1), 140-163.

Erasmus, C \& Mans G 2004. Report: Transformation research project in Paarl/Wellington. http://academic.sun.ac.za/theology/egdn/trp/trp.htm

Fals-Borda, O \& Rahman, M A 1991. Action and knowledge: Breaking the monopoly with participatory action research. New York: The Apex Press.

Froise, M \& Hendriks, H J 1999. South African Christian Handbook 1999-2000. Welkom: Christian Info.

Hall, J D 1991. Thinking the faith: Christian theology in a North American context. Minneapolis, MN: Fortress.

Heitink, G 1999. Practical Theology: History, theory, action domains. Grand Rapids, MI: Eerdmans.

Hendriks, H J \& Erasmus J C \& Mans G 2004. Congregations as providers of social service and HIVIAids care. NGTT Supple 45(2), 380-402.

Hendriks, H J \& Erasmus, J C 2001. Interpreting the new religious landscape in postApartheid South Africa. Journal of Theology for Southern Africa 109, 41-65.

Hendriks, H J \& Erasmus, J C 2005. Religion in South Africa: The 2001 population census data. Journal of Theology for Southern Africa 121, 88-111.

Hendriks, H J 2003. Die toekoms van die kerk, die kerk van die toekoms: Intreerede/The future of the church, the church of the future: Inaugural lecture, 1-24. Stellenbosch: Universiteit Stellenbosch Drukkery.

Jones, C 1997. Geographical information systems and computer cartography. Edinburgh Gate: Addison Wesley Longman.

Murdie, R A 1969. Factorial ecology of metropolitan Toronto, Research paper 116. Chicago, IL: Department of Geography, University of Chicago.

Prozesky, H \& Mouton, J 2001. The participatory research paradigm, in Coetzee, J K (ed) et al, Development: theory, policy, and practice, 537-550. Oxford: University Press.

Queralt, M \& Witte, A D 1998. A map for you? Geographical information systems in the social service. Social Work 43(5), 455-467.

Rahman, M A 1993. People's self-development: Perspectives on participatory action research. London: Zed Books.

Schurink, E M 1998. Participatory action research as a tool for sustainable social development and reconstruction, in De Vos, A S (ed), Research at grass roots, 405-418. Pretoria: J L van Schaik.

Schutte, DeW. (2000). People first: Determining priorities for community development. Ebony Books: Parow East. 
Swart, I \& Venter D 2001. NGOs and churches: Civil society actors and the promise of fourth generation development in South Africa, in Coetzee, J K (ed) et al, Development: Theory, policy, and practice, 482-495. Oxford: University Press.

Van der Ven, J 1998. Practical Theology: An empirical approach. Leuven: Peeters. Figure 1: Orientation map and places of worship

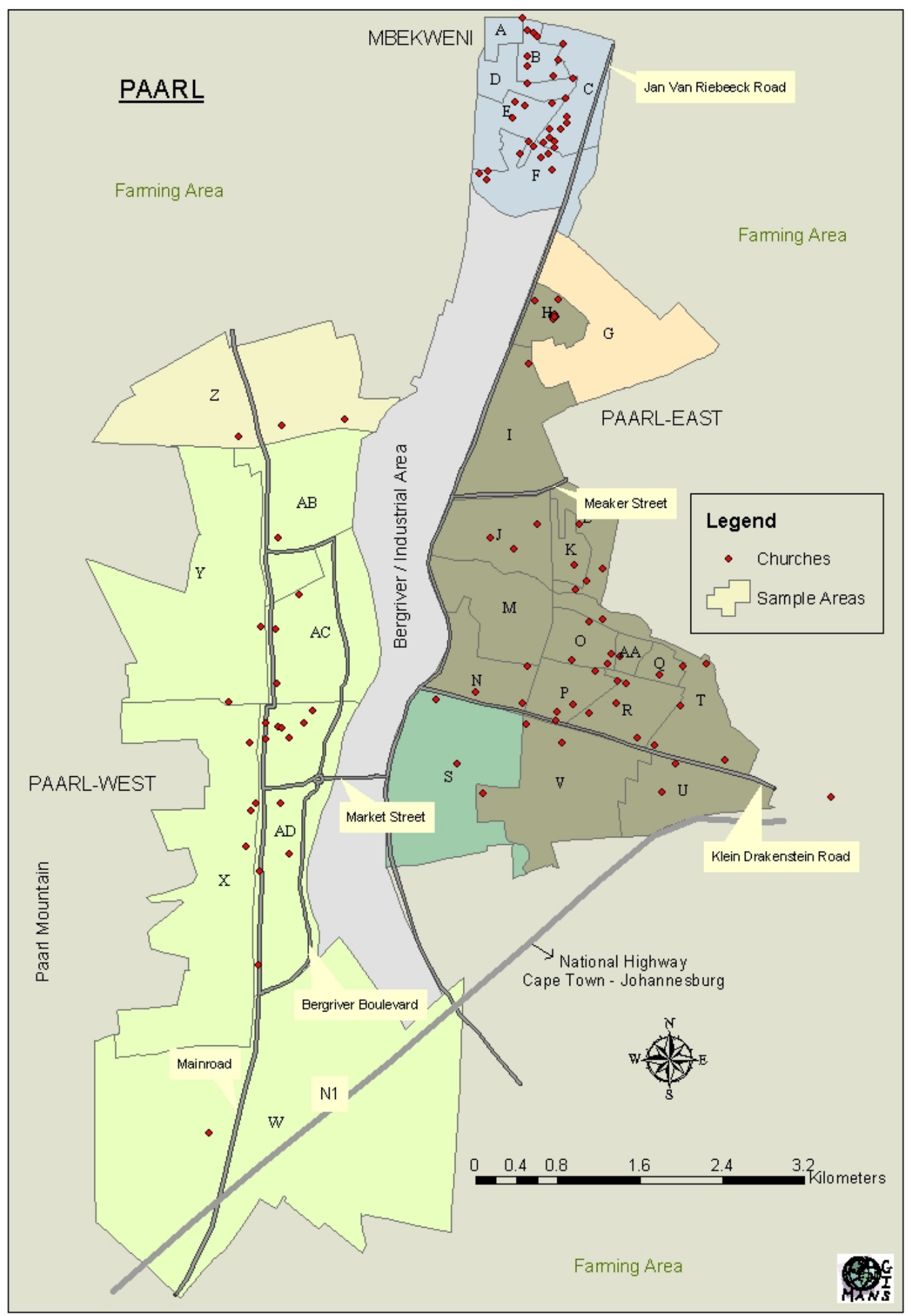





\begin{tabular}{|c|c|c|c|c|c|c|c|c|c|c|c|}
\hline \multicolumn{4}{|c|}{ Direct } & \multicolumn{4}{|c|}{ Preventative } & \multicolumn{4}{|c|}{ Counselling } \\
\hline SV & $\mathrm{H} / \mathrm{A}$ & Un & Ave & SV & $\mathrm{H} / \mathrm{A}$ & Un & Ave & SV & $\mathrm{H} / \mathrm{A}$ & Un & Ave \\
\hline $13.7 \%$ & $12.3 \%$ & $10.2 \%$ & $12.1 \%$ & $11.2 \%$ & $15.1 \%$ & $9.3 \%$ & $11.9 \%$ & $11.7 \%$ & $13.0 \%$ & $9.5 \%$ & $11.4 \%$ \\
\hline
\end{tabular}

\begin{tabular}{|c|c|c|c|c|c|c|c|c|c|c|c|}
\hline \multicolumn{4}{|c|}{ Direct } & \multicolumn{4}{|c|}{ Preventative } & \multicolumn{4}{|c|}{ Counselling } \\
\hline SV & $\mathrm{H} / \mathrm{A}$ & Un & Ave & SV & $\mathrm{H} / \mathrm{A}$ & Un & Ave & SV & $\mathrm{H} / \mathrm{A}$ & Un & Ave \\
\hline $11.0 \%$ & $11.2 \%$ & $8.3 \%$ & $10.2 \%$ & $10.6 \%$ & $12.4 \%$ & $8.5 \%$ & $10.5 \%$ & $10.7 \%$ & $10.8 \%$ & $9.0 \%$ & $10.2 \%$ \\
\hline
\end{tabular}

\begin{tabular}{|c|c|c|c|c|c|c|c|c|c|c|c|c|c|c|c|c|c|c|c|}
\hline \multicolumn{4}{|c|}{ Certainly not } & \multicolumn{4}{|c|}{ No } & \multicolumn{4}{|c|}{ Unsure } & \multicolumn{4}{|c|}{ Yes } & \multicolumn{4}{|c|}{ Certainly } \\
\hline SV & $\mathrm{H} / \mathrm{A}$ & Un & Ave & SV & $\mathrm{H} / \mathrm{A}$ & Un & Ave & SV & $\mathrm{H} / \mathrm{A}$ & Un & Ave & SV & $\mathrm{H} / \mathrm{A}$ & Un & Ave & SV & $\mathrm{H} / \mathrm{A}$ & Un & Ave \\
\hline $1.1 \%$ & $1.2 \%$ & $1.4 \%$ & $1.2 \%$ & $4.1 \%$ & $6.7 \%$ & $6.3 \%$ & $5.7 \%$ & $18.8 \%$ & $23.1 \%$ & $27.8 \%$ & $23.3 \%$ & $45.0 \%$ & $45.0 \%$ & $46.6 \%$ & $45.5 \%$ & $30.9 \%$ & $23.9 \%$ & $18.5 \%$ & $24.4 \%$ \\
\hline
\end{tabular}

\begin{tabular}{|c|c|c|c|c|c|c|c|c|c|c|c|c|c|c|c|c|c|c|c|}
\hline \multicolumn{4}{|c|}{ Certainly not } & \multicolumn{4}{|c|}{ No } & \multicolumn{4}{|c|}{ Unsure } & \multicolumn{4}{|c|}{ Yes } & \multicolumn{4}{|c|}{ Certainly } \\
\hline SV & $\mathrm{H} / \mathrm{A}$ & Un & Ave & SV & $\mathrm{H} / \mathrm{A}$ & Un & Ave & SV & $\mathrm{H} / \mathrm{A}$ & Un & Ave & SV & $\mathrm{H} / \mathrm{A}$ & Un & Ave & SV & $\mathrm{H} / \mathrm{A}$ & Un & Ave \\
\hline $1.4 \%$ & $1.2 \%$ & $2.5 \%$ & $1.7 \%$ & $7.5 \%$ & $6.0 \%$ & $12.9 \%$ & $8.8 \%$ & $23.1 \%$ & $20.4 \%$ & $28.5 \%$ & $24.0 \%$ & $47.3 \%$ & $48.6 \%$ & $36.4 \%$ & $44.1 \%$ & $20.7 \%$ & $23.8 \%$ & $19.7 \%$ & $21.4 \%$ \\
\hline
\end{tabular}

\begin{tabular}{|c|c|c|c|c|c|c|c|c|c|c|c|c|c|c|c|c|c|c|c|}
\hline \multicolumn{4}{|c|}{ Certainly not } & \multicolumn{4}{|c|}{ No } & \multicolumn{4}{|c|}{ Unsure } & \multicolumn{4}{|c|}{ Yes } & \multicolumn{4}{|c|}{ Certainly } \\
\hline SV & $\mathrm{H} / \mathrm{A}$ & Un & Ave & SV & $\mathrm{H} / \mathrm{A}$ & Un & Ave & SV & $\mathrm{H} / \mathrm{A}$ & Un & Ave & SV & $\mathrm{H} / \mathrm{A}$ & Un & Ave & SV & $\mathrm{H} / \mathrm{A}$ & Un & Ave \\
\hline $1.2 \%$ & $1.4 \%$ & $1.6 \%$ & $1.4 \%$ & $4.9 \%$ & $4.8 \%$ & $5.4 \%$ & $5.0 \%$ & $20.7 \%$ & $21.1 \%$ & $24.5 \%$ & $22.1 \%$ & $52.0 \%$ & $50.7 \%$ & $51.3 \%$ & $51.3 \%$ & $21.2 \%$ & $22.0 \%$ & $17.2 \%$ & $20.1 \%$ \\
\hline
\end{tabular}

\begin{tabular}{|c|c|c|c|c|c|c|c|c|c|c|c|c|c|c|}
\hline \multicolumn{5}{|c|}{ Co-operation between churches } & \multicolumn{5}{|c|}{ Church does not care for poor } & \multicolumn{5}{|c|}{ Church should co-operate with Gov/NGOs } \\
\hline $\begin{array}{l}\text { Disagree } \\
\text { Strongly }\end{array}$ & Disagree & Unsure & Agree & $\begin{array}{l}\text { Agree } \\
\text { Strongly }\end{array}$ & $\begin{array}{l}\text { Disagree } \\
\text { Strongly }\end{array}$ & Disagree & Unsure & Agree & $\begin{array}{l}\text { Agree } \\
\text { Strongly }\end{array}$ & $\begin{array}{l}\text { Disagree } \\
\text { Strongly }\end{array}$ & Disagree & Unsure & Agree & $\begin{array}{c}\text { Agree } \\
\text { Strongly }\end{array}$ \\
\hline $0.8 \%$ & $0.4 \%$ & $7.3 \%$ & $43.2 \%$ & $48.3 \%$ & $22.9 \%$ & $32.2 \%$ & $22.0 \%$ & $15.9 \%$ & $6.9 \%$ & $1.0 \%$ & $3.4 \%$ & $14.8 \%$ & $51.0 \%$ & $29.8 \%$ \\
\hline
\end{tabular}

